\title{
Pengaruh Model Pembelajaran Inkuiri Terbimbing Berbantuan Simulasi Virtual Terhadap Penguasaan Konsep Fisika Peserta Didik SMA
}

\author{
Sumarni, Kosim*, Ni Nyoman Sri Putu Verawati \\ Program Studi Pendidikan Fisika, Universitas Mataram \\ *Email: kosim_fisika@unram.ac.id
}

Received: 31 Agustus 2020; Accepted: 27 November 2020; Published: 15 Desember 2020

DOI: http://dx.doi.org/10.29303/jpft.v6i2.2042

\begin{abstract}
This study aims to determine the effect of guided inquiry learning models assisted by virtual simulations on the mastery of physics concepts for high school students. This type of research is a quasiexperimental with a pretest-posttest control group design. The study population was all students of class XI MIA SMAN 1 Sheet, totaling 53 students with the sampling technique using purposive sampling technique, so the sample used in this study was class XI MIA-2 as an experimental class totaling 26 students and class XI MIA. -3 as a control class, totaling 27 students. Before being given treatment, the two samples were given an initial test to determine their initial ability. The results show that the the ability of both class control and experiment are homogen. That means before doing the treatment, they have the same abilty. The research hypothesis was tested by using polled variance t-test with a significance level of 5\%. Based on the results of data analysis, $t$ count is greater than t table, so that HO is rejected and $\mathrm{Ha}$ is accepted. Thus, it can be concluded that the guided inquiry learning model assisted with virtual simulations has an effect on the mastery of physics concepts for high school students.
\end{abstract}

Keywords: guided inquiry learning model, virtual simulation, mastery of concepts

\section{PENDAHULUAN}

Fisika merupakan cabang IPA (sains), dimana pada hakikatnya merupakan kumpulan pengetauan, cara penyelidikan, dan cara berfikir. Pembelajaran fisika menekankan pada pemberian pengalaman langsung untuk mengembangkan kompetensi peserta didik. Pengetahuan fisika yang diperoleh melalui serangkaian proses ilmiah seperti melakukan pengukuran, percobaan dan diskusi serta melibatkan peserta didik secara langsung dalam kegiatan tersebut akan membantu mereka memahami konsep-konsep yang ada Gunawan (2015).

Berdasarkan hasil observasi berupa interview pada suatu proses pembelajaran fisika di SMAN 1 Lembar pada tanggal 23 Oktober 2018, tampak bahwa dalampembelajaran fisika guru kurang memvariasikan model pembelajaran dan cenderung proses pembelajaran masih berpusat pada guru. Peserta didikjuga kurang aktif dalam proses pembelajaran, peserta didik cendrung menghafal rumus tanpa memahami konsep dan peserta didik menganggap pelajaran fisika terlalu sulit. Kurangnya minat belajar peserta didik menyebabkan penguasaan konsep masih rendah, oleh karena itu, perlu dilakukan perubahan paradigma proses pembelajaran yaitu perubahan dari pembelajaran yang bersifat teacher centeredke pembelajaran yang berorientasi pada peserta didik aktif (student centered).

Salah satu upaya yang dapat digunakan untuk mengatasi masalah tersebut adalah dengan menggunakan model inkuiri, dalam hal ini adalah model inkuiri terbimbing (guided inquiry). Menurut Nurmayani (2018), model pembelajaran inkuiri terbimbing merupakan model pembelajaran yang melibatkan peserta didik secara aktif mulai dari merumuskan masalah hingga menarik kesimupulan.Kelebihan model inkuiri terbimbing (guided inquiry) 
adalah guru tidak melepas begitu saja kegiatan-kegiatan yang dilakukan oleh peserta didik, sehingga peserta didik yang berifikir lambat atau peserta didik yang mempunyai intelegensi rendah tetap mampu mengikuti kegiatan yang sedang dilaksanakan dan peserta didik yang mempunyai kemampuan berpikir tinggi tidak memonopoli kegiatan.

Menurut Wahyuni (2016) mengatakan bahwa terdapat pengaruh model pembelajaran inkuiri terbimbing dengan metode eksperimen terhadap hasil belajar fisika. Karena, model pembelajaran inkuiri terbimbing dengan metode eksperimen yang diberikan pada kelas eksperimen membuat siswa lebih aktif dalam belajar dan meningkatkan hasil belajar fisika siswa. Nuari (2016) mengatakan bahwa terdapat pengaruh model pembelajaran inkuiri terbimbing terhadap hasil belajar. Karena, dengan menggunakan model pembelajaran inkuiri terbimbing membuat suasana pembelajaran menjadi semarak, hasil pembelajaran siswa meningkat dan siswa sangat antusias dalam pembelajaran, tidak mengantuk dan tidak merasa bosan.

Model pembelajaran inkuiri tidak lepas dari eksperimen di laboratorium. Kegiatan laboratorium akan berlangsung dengan baik bila ditunjang oleh sarana dan prasarana laboratorium yang memadai. Fakta yang ditemui di lapangan mengungkapkan bahwa alat-alat laboratorium umumnya masih kurang lengkap atau bahkan tidak ada sama sekali. Hal ini menyebabkan, guru jarang sekali melakukan kegiatan praktikum.

Salah satu alternatif yang dapat digunakan apabila alat-alat laboratorium kurang memadai adalah media yang berbentuk simulasi virtual. Gunawan (2015) Simulasi virtual bertujuan agar peserta didik memiliki kesempatan untuk belajar dan menerapkan keterampilan dunia nyata.
Simulasi virtual bisa digunakan untuk melakukan eksperimen maupun demonstrasi. kesempatan untuk belajar dan menerapkan keterampilan dunia nyata. Simulasi virtual bisa digunakan untuk melakukan eksperimen maupun demonstrasi.

Beberapa penelitian yang telah dilakukan tentang penggunaan simulasi virtual terhadap penguasaan konsep peserta didik, menurut Hayati(2017) menyatakan bahwa penggunaan media simulasi dalam pembelajaran inkuiri berpengaruh terhadap hasil belajar fisika peserta didik. Karena, tersedianya visualisasi konsep dengan bantuan laboratorium virtual yang disajikan pada setiap materi membuat peserta didik pada kelas eksperimen lebih mudah memahami materi yang dipelajari dibandingkan kelas kontrol. Suhandi (2009) menyimpulkan bahwa penggunaan simulasi virtual pada pendekatan pembelajaran konseptual interaktif dapat lebih meningkatkan efektifitasnya dalam meningkatkan pemahaman konsep peserta didik dan meminimalkan miskonsepsi. Penggunaan simulasi virtual dalam pembelajaran dapat memberikan peserta didik pengalaman untuk menemukan konsep itu sendiri.

Berdasarkan pemaparan di atas perlu dilakukan penelitian " Apakah model pembelajaran inkuiri terbimbing berbantuan simulasi virtual berpengaruh terhadap penguasaan konsep fisika peserta didik ?

Menurut Anam (2016) inkuiri berasal dari kata inquiry yang merupakan kata dalam bahasa Inggris yang berarti; penyelidikan atau meminta keterangan; terjemahan bebas untuk konsep ini adalah "peserta didik diminta untuk mencari dan menemukan sendiri jawaban dari suatu masalah yang diberikan"

Menurut Wahyudi (2013) model pembelajaran inkuiri terbimbing merupakan 
model pembelajaran yang membantu peserta didik untuk belajar, membantu peserta didik memperoleh pengetahuan dengan cara menemukan sendiri. Adapun tahap-tahap pembelajarannya menurut Trianto (2014) yaitu mengajukan pertanyaan atau masalah, merumuskan hipotesis, mengumpulkan data, analisis data, dan membuat kesimpulan.

Simulasi virtual dimaksudkan untuk mentransfer pengetahuan baik konseptual maupun prosedural.Simulasi virtual bisa digunakan untuk melakukan kegiatan eksperimen atau demonstrasi. Sebagaimana yang telah dijelaskan oleh Gunawan (2013) dari hasil penelitiannya dapat disimpulkan keuntungan melakukan kegiatan eksperimen menggunakan simulasi virtual antara lain : kegiatan praktikum menjadi lebih efisien dan murah karena setiap tahapan percobaan sudah tersedia dalam software pembelajaran, tidak memerlukan biaya perawatan yang mahal, kegiatan praktikum menjadi lebih aman karena tidak ada gangguan yang dapat membahayakan praktikan ketika praktikum berlangsung. Simulasi virtual yang digunakan berupa simulasi yang sudah ada yakni program Phet Interactive Simulations yang telah dipatenkan oleh Universitas Colorado.

Tabel 1. Sintaks Model Pembelajaran Inkuiri Terbimbing berbantuan Simulasi Virtual

Fase

\section{Perilaku Guru}

1. Menyanjikan Guru membimbing peserta didik pertanyaan atau mengidentifikasi masalah dan masalah masalah di tuliskan di papan tulis. Guru membagi peserta didik dalam kelompok

2. Membuat hipotesis
Guru memberikan kesempatan pada peserta didik untuk curah pendapat dalam membentuk hipotesis.

Guru membimbing peserta didik dalam menentukan hipotesis yang relevan dengan permasalahan dan memprioritaskan hipotesis mana yang menjadi prioritas penyelidikan

\section{Fase Perilaku Guru}

3. Merancang Guru membimbing peserta didik percobaan mempersiapkan kegiatan (Simulasi percobaan menggunakan simulasi Virtual) virtualGuru menjelaskan target yang diharapkan dari percobaan menggunakan simulasi virtual

4. Melakukan Guru membimbing peserta didik percobaan mendapatkan informasi melalui untuk Percobaan

memperoleh

informasi

(Simulasi

Virtual)

5. Mengumpulkan Guru memberikan kesempatan dan menganalisis data pada tiap kelompok untuk menyampaikan hasil pengolahan data yang terkumpul

6. Membuat kesimpulan

Guru membimbing peserta didik dalam membuat kesimpulan

(Trianto, 2014)

\section{A. Penguasaan Konsep}

Menurut Anderson \& Krathwohl (2015) mengungkapkan bahwa pengetahuan konseptual mencakup pengetahuan mengenai kategori, klasifikasi, dan hubungan antara dua atau lebih kategori atau klasifikasi pengetahuan yang lebihkompleks.

Silaban

(2014),

Bloom mengemukakan penguasaan konsep sebagai suatu kemampuan menangkap pengertianpengertian seperti mampu mengungkapkan suatu materi yang disajikan ke dalam bentuk yang lebih dipahami, mampu memberikan interpretasi dan mampu mengaplikasikannya.

Taksonomi Bloom pada ranah kognitif terdiri dari 6 bagian yang biasa dikenal dengan $\mathrm{C} 1$ sampai $\mathrm{C} 6$ yaitu, $\mathrm{C} 1$ pengetahuan (knowledge), $\quad \mathrm{C} 2 \quad$ pemahaman (comprehension), $\quad \mathrm{C} 3$ penerapan (application), C4 analisis (analysis), C5 sintesis (synthesis), dan C6 evaluasi (evaluation).

Penguasaan konsep dalam penelitian ini diukur pada ranah kognitif, digunakan taksonomi Bloom yang sudah direvisi 
seperti yang digagas oleh Aderson dan Kratwohl (2015), yakni mengingat adalah kegiatan menggunakan memori untuk memproduksi suatu definisi, fakta, daftar istilah, rumus dan produk pengetahuan siap pakai lainnya. Memahami adalah membangun suatu pengertian dari bebeapa pengertian yang berbeda. Mengaplikasi berkaitan dengan pengetahuan procedural yang digunakan untuk menyelesaikan berbagai permasalahan. Menganalisis adalah memecah suatu konsep ke dalam bagianbagian tertentu. Mengevaluasi adalah meberikan penelitian terhdap suatu produk pengetahuan berdasarkan kriteria atau standar tertentu, dan mencipta adalah kegiatan menyatukan bebrapa unsur pengetahuan yang berbeda sehingga membentuk struktur atau pola pengetahuan baru.

\section{METODE PENELITIAN}

Jenis penelitian yang digunakan adalah Quasi Eksperimendengan desain penelitian pretest-posttest control grup design.Penelitian ini melibatkan tiga variabel yaitu variabel bebas berupa model pembelajaran inkuiri terbimbing berbantuan simulasi virtual, variabel terikat berupa penguasaan konsep dan variabel kontrol berupa materi ajar pada impuls dan momentum, peneliti sebagai guru dan instrumen penilaian berupa pilihan ganda.

Populasi dalam penelitian ini adalah seluruh peserta didik kelas XI MIA SMAN 1 Lembar tahun pelajaran 2019/2020. Teknik pengambilan sampel yang digunakan adalah purposive sampling. Berdasarkan hasil interview dengan guru fisika di sekolah tersebut, sampel yang digunakan adalah kelas XI MIA-2 yang berjumlah 26 peserta didik sebagai kelas eksperimen dan sebagai kelas kontrol adalah kelas XI MIA-3 yang berjumlah 27 peserta didik.
Instrumen penelitian yang digunakan adalahuraian. Setelah diuji validitas, realibilitas, tingkat kesukaran, dan daya beda soal diperoleh 10 soal yang tersebar pada setiap sub materi.

Uji hipotesis dalam penelitian ini menggunakan uji-t Polled Varians dengan taraf signifikan 5\% dan derajat kebebasan $\left(n_{1}+n_{2}\right)-2$ dengan syarat telah terdistribusi normal dan homogen.

Penelitian ini dilakukan dengan memberikan perlakuan pada kelas eksperimen berupa model pembelajaran inkuiri terbimbing berbantuan simulasi virtual dan menerapkan pembelajaran konvensional pada kelas kontrol. Kedua kelas diberikan perlakuan selama tiga kali pertemuan dengan alokasi waktu setiap pertemuan selama 90 menit atau 2 jam pelajaran dengan materi elastisitas.

\section{HASIL DAN PEMBAHASAN}

Penelitian ini bertujuan untuk mengetahui pengaruh model pembelajaran inkuiri terbimbing berbantuan simulasi virtual terhadap penguasaan konsep fisika peserta didik SMA yang dilakukan pada peserta didik kelas XI MIA SMAN 1 Lembar. Penelitian dilakukan dengan memberikan perlakuan berupa penerapan model pembelajaran inkuiri terbimbing berbantuan simulasi virtual pada kelas XI MIA 2 sebagai kelas eksperimen dan pembelajaran konvensional pada kelas XI MIA 3 sebagai kelas kontrol. Pengambilan data penelitian dilakukan sebelum dan sesudah diberikan perlakuan pada kedua kelas yaitu pada hasil tes awal dan tes akhir peserta didik.

Hasil tes awal penguasaan konsep fisika baik pada kelas eksperimen maupun kelas kontrol termasuk dalam kategori rendah. Hal ini terlihat dari nilai rata-rata tes penguasaan konsep masing-masing kelas, yaitu untuk kelas eksperimen adalah 43,27 
dan untuk kelas kontrol adalah 52,56. Hal ini disebabkan karena peserta didik belum mendapat perlakuan, materi tentang elastisitas belum pernah diajarkan dan pengetahuan yang dimiliki hanya berupa pengetahuan dasar yang diperoleh dalam kehidupan sehari-hari. Selain itu, kurangnya kemampuan awal peserta didik untuk menghubungkan pengetahuan yang lama dengan pengetahuan baru dan bagaimana mengkonstrusikan pengetahuan tersebut, sehingga solusi yang diterapkan oleh Peneliti adalah menerapkan model pembelajaran inkuiri terbimbing berbantuan simulasi virtual dalam proses pembelajaran. Berdasarkan hasil uji homogenitas tes awal yang telah dilakukan, diperoleh bahwa kedua sampel (kelas eksperimen dan kelas kontrol) homogen, yang berarti kedua kelas memiliki kemampuan awal yang sama, maka kedua kelas dapat diberikan perlakuan.

Kelas eksperimen diberikan perlakuan model pembelajaran inkuiri terbimbing berbantuan simulasi virtual, sedangkan kelas kontrol diberikan perlakuan model pembelajaran konvensional di sekolah, yakni model pembelajaran langsung tanpa berbantuan simulasi virtual.

Penerapan model pembelajaran inkuiri terbimbing di kelas eksperimen memberikan hasil yang lebih baik terhadap penguasaan konsep peserta didik dibandingkan dengan kelas kontrol yang diterapkan model pembelajaran konvensional, hal tersebut dapat dilihat pada Tabel 2 dimana terlihat bahwa hasil tes penguasaan konsep menunjukkan adanya peningkatan yang lebih tinggi pada tes akhir kelas eksperimen dibandingkan kelas kontrol. Hasil analisis tes akhir penguasaan konsep yang telah dilakukan didapatkan nilai rata-rata kelas eksperimen sebesar 68,69 sedangkan nilai rata-rata kelas kontrol sebesar 59,67.

Tabel 2. Data Hasil Tes Awal dan Tes Akhir Kelas Eksperimen dan KelasKontrol

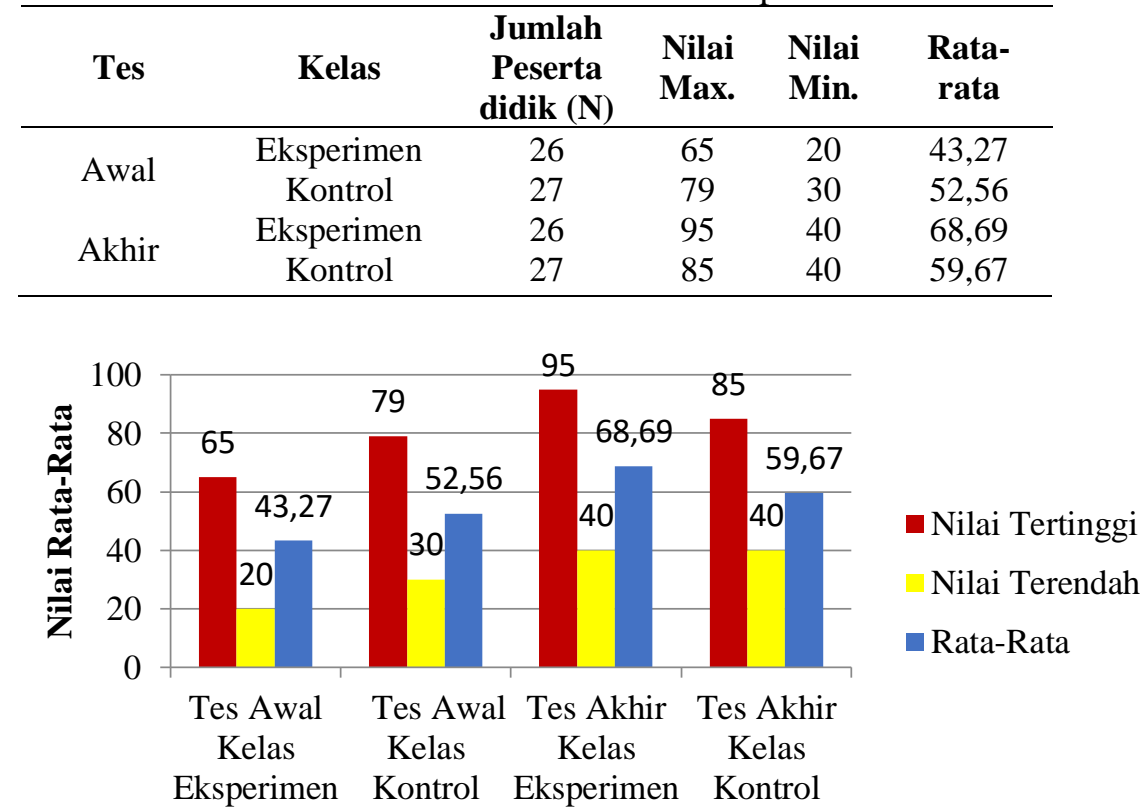

Gambar 1. Data Hasil Tes Awal dan Tes Akhir Kelas Eksperimen dan Kelas Kontrol

Tabel 3. Hasil Uji Homogenitas dan Normalitas Kelas Eksperimen dan Kelas Kontrol

\begin{tabular}{cccccc}
\hline Kelas & \multicolumn{2}{c}{ Tes Awal } & \multicolumn{2}{c}{ Tes Akhir } & Keterangan \\
& $F_{\text {hitung }}$ & $F_{\text {tabel }}$ & $F_{\text {hitung }}$ & $F_{\text {tabel }}$ & \\
\hline $\begin{array}{c}\text { Eksperimen } \\
\text { Kontrol }\end{array}$ & 1.25 & 1,92 & 1.04 & 2.07 & Homogen \\
\hline
\end{tabular}


Tabel 4. Hasil Uji Normalitas Tes Akhir Kelas Eksperimen dan Kelas Kontrol

\begin{tabular}{cccc}
\hline Kelas & $\boldsymbol{X}^{2}{ }_{\text {hitung }}$ & $\boldsymbol{X}^{\mathbf{2}}$ tabel & Keterangan \\
\hline Eksperimen & 9,92 & \multirow{2}{*}{11.07} & Terdistribusi Normal \\
Kontrol & 7.27 & & Terdistribusi Normal \\
\hline
\end{tabular}

Berdasarkan hasil tes akhir, kedua kelas sama-sama mengalami peningkatan Jika dibandingkan dengan nilai rata-rata pada tes awal. Sementara untuk mengetahui perbedaan peningkatan yang dialami oleh kedua kelas secara kuantitatif serta pengaruh dari model yang diberikan, maka perlu dilakukan uji hipotesis. Uji hipotesis yang digunakan dalam penelitian ini adalah uji-t polled varians karena sampel merupakan kelas yang homogen seperti yang terlihat pada Tabel 3 dan data yang dihasilkan terdistribusi normal seperti yang terlihat pada Tabel 4.

Berdasarkan hasil perhitungan uji-t polled varians dalam menguji hipotesis penelitian, telah diperoleh $t_{\text {hitung }}=2,25$ sedangkan $t_{\text {tabel }}=2.00$ dengan tingkat signifikansi $5 \%$. Hal ini menunjukkan bahwat $_{\text {hitung }}>t_{\text {tabel }}$ yaitu 2,25 $>$ 2.00,yang berarti Ho ditolak. Hal ini menunjukkan bahwa kelas eksperimen yang diberikan perlakuan berupa penerapan model pembelajaran inkuiri terbimbing berbantuan simulasi virtual berpengaruh terhadap penguasaan konsep fisika peserta didik.

Hasil ini diperkuat beberapa penelitian sebelumnya, seperti penelitian yang dilakukan sabahiyah(2013) menyatakan bahwa model pembelajaran inkuiri terbimbing berpengaruh terhadap peningkatan penguasaan konsep peserta didik, karena peserta didik yang menemukan sendiri konsep yang dipelajarinya secara langsung melalui kegiatan ilmiah sehingga konsep-konsep tersebut akan lebih mudah dipahami dan akan melekat pada pikiran peserta didik dan sulit untuk dilupakan. Hal ini juga didukung oleh penelitian yang dilakukan oleh hermansyah (2017), menyatakan bahwa penggunaan laboratorium virtual dalam pembelajaran inkuiri terbimbing berpengaruh terhadap penguasaan konsep peserta didik. Karena, kelompok eksperimen menggunakan laboratorium virtual dalam pembelajaran inkuiri yang mampu memberikan kesempatan pada peserta didik untuk lebih leluasa dalam melakukan praktikum secara mandiri tanpa rasa takut akan terjadi kerusakan saat melakukan eksperimen.

Penelitian terkait dengan penggunaan simulasi virtual dalam pembelajaran, antara lain Suhandi (2009), yang mengatakan penggunaan simulasi virtual pada pendekatan pembelajaran konseptual interaktif dapat lebih meningkatkan efektifitasnya dalam meningkatkan pemahaman konsep peserta didik dan meminimalkan miskonsepsi. Penggunaan simulasi virtual dalam pembelajaran dapat memberikan peserta didik pengalaman untuk menemukan konsep itu sendiri. Arianti (2016) menyatakan bahwa terdapat pengaruh penerapan model direct instruction berbantuan simulasi virtual terhadap pengasaan konsep dan pemecahan masalah fisika siswa. Selain itu,menurut Jauhari (2016) menyatakan bahwa kelas eksperimen yang diberikan perlakuan model pembelajaran berbasis masalah berbantuan media PhET, lebih aktif dan antusias saat mengikuti proses pembelajaran serta memilki kemampuan akhir kognitif yang lebih tinggi dilihat dari peningkatan hasil belajarnya daripada kelas 
kontrol yang diberikan perlakuan model pembelajaran konvensional.

\section{PENUTUP}

Berdasarkan hasil tes akhir, kedua kelas sama-sama mengalami peningkatan Jika dibandingkan dengan nilai rata-rata pada tes awal. Berdasarkan uji hipotesis, dapat disimpulkan bahwa model pembelajaran inkuiri terbimbing berbantuan simulasi virtual berpengaruh terhadap penguasaan konsep fisika peserta didik kelas XI MIA SMAN 1 Lembar. Model inkuiri terbimbing berbantuan simulasi virtual yang diterapkan pada kelas eksperimen mampu meningkatkan penguasaan konsep yang lebih tinggi.

Model pembelajaran inkuiri terbimbing berbantuan simulasi virtual ini dapat diterapkan untuk meningkatkan penguasaan konsep fisika peserta didik dengan memperhatikan beberapa hal, yaitu: Waktu belajar direncanakan dan dialokasikan dengan efektif agar setiap tahap pembelajaran berlangsung dengan baik.

Selain itu, Guru seyogyanya dapat menerapkan model pembelajaran inkuiri terbimbing berbantuan simulasi virtual untuk meningkatkan penguasaan konsep fisika peserta didik pada materi ajar yang lain.

\section{REFERENSI}

Anam, K. (2016). Pembelajaran Berbasis Inkuiri; Metode dan Aplikasi. Yogyakarta: Pustaka Belajar.

Anderson,L.W \& Krathwohl, D.R. (2015). Kerangka Landasan untuk Pembelajaran, Pengajaran, dan Aseseman Revisi Taksonomi Pendidikan Bloom. Bandung: Alfabeta.

Arianti, B. I., Sahidu, H., Harjono, A., \& Gunawan. 2016. Pengaruh Model Direct Instruction Berbantuan Simulasi Virtual Terhadap
Penguasaan Konsep Siswa. Jurnal Pendidikan Fisika dan Teknologi, 2(4).

Gunawan. 2015. Model Pembelajaran Sains Berbasis ICT. Mataram: FKIP UNRAM.

Gunawan., Setiawan, A. \& Widyantoro, D.H. 2013. Model Virtual Laboratory Fisika Modern untuk Meningkatkan Keterampilan Generik Sains Calon Guru. Jurnal Pendidikan dan Pembelajaran, 20(1).

Hayati, S. N., Hikmawati, H., \& Wahyudi, W. 2017. Pengaruh Model Pembelajaran Inkuiri dengan Menggunakan Media Simulasi Terhadap Hasil Belajar Fisika Siswa Kelompok X MIA SMAN 1 Lingsar Lombok Barat Tahun Pelajaran 2016/2017. Jurnal Pendidikan Fisika dan Teknologi, 3(1).

Hermansyah, Gunawan \& Harjono, A. 2017. Pengaruh Penggunaan Laboratorium Virtual dalam Pembelajaran Inkuiri Terbimbing terhadap Penguasaan Konsep Kalor Peserta Didik. Jurnal Pendidikan Fisika dan Teknologi, 3(2).

Jauhari, T., Hikmawati \& Wahyudi. 2016. Pengaruh Model Pembelajaran Berbasis Masalah Berbantuan Media PhET terhadap Hasil Belajar Fisika Siswa Kelas X SMAN 1 Gunung Sari Tahun Ajaran 2015/2016. Jurnal Pendidikan Fisika dan Teknologi, 2(1).

Nuari, A. J, Lestari,R \& Dahlia. Pengaruh Model Pembelajaran Inkuiri Terbimbing terhadap Hasil Belajar Siswa Kelas X Di SMAN 1 Rambah Tahun Pembelajaran 2015/2016. Journal Mahasiswa Prodi Biologi UPP.

Nurmayani, L., Doyan, A., \% Verawati, N.N.S.P. 2018. Pengaruh Model Pembelajaran Inkuiri Terbimbing terhadap Kemampuan Berpikir Kritis. Jurnal Pendidikan Fisika dan Teknologi, 4(1). 
Sabahiyah, Marhaeini, A.A.I.N \& Suastra. Pengaruh Model Pembelajaran Inkuiri Terbimbimbing Terhadap Proses Sains dan Penguasaan Konsep Ipa Siswa Kelas V Gugus 03 Wanasaba Lombok Timur. E- Journal Program Pascasarjana Universitas Pendidikan Ganesha, 3.

Silaban, B. 2014. Hubungan Antara Penguasaan Konsep Fisika dan Kreativitas dengan Kemampuan Memecahkan Masalah pada Materi Listrik Statis. Jurnal Penelitian Bidang Pendidikan, 20(1).

Suhandi, A., Sinaga, P., Kaniawati, I., \& Suhendi, E. (2009). Efektivitas penggunaan media simulasi virtual pada pendekatan pembelajaran konseptual interaktif dalam Meningkatkan pemahaman konsep dan meminimalkan miskonsepsi. Jurnal Pengajaran MIPA, 13(1).

Trianto. 2014. Mendesain Model Pembelajaran Inovatif-Progresif. Jakarta: Prestasi Pustaka.

Wahyudi, L.E \& Supardi, I. 2013. Pene2rapan Model Pembelajaran Inkuri Terbimbing pada Pokok Bahsan Kalor untuk Melatihkan Keterampilan Sains terhadap Hasil Belajar di SMAN 1 SUMENEP. Jurnal Inovasi Pendidikan Fisika, 2(2).

Wahyuni, R., Hikmawati, H., \&Taufik, M. 2016. Pengaruh Model Pembelajaran Inkuiri Terbimbing dengan meetode Eksperimen terhadap Hasil Belajar Fisika Siswa Kelas XI IPA SMAN 2 Mataram Tahun Pelajaran 2016/2017. Jurnal Pendidikan Fisika dan Teknologi, 2(2). 